Sri Lanka J. Aquat. Sci. 14 (2009): 1-13

\title{
Status of the fishery of flying fish off northwestern coast of Sri Lanka and the effect of lunar pattern on catchability
}

\author{
M.D.S.T. DE CROOS* \\ Department of Aquaculture and Fisheries, Wayamba University of Sri Lanka, \\ Makandura, Gonawila (NWP), Sri Lanka \\ *E-mail: dileepa_dc@yahoo.com
}

\begin{abstract}
In Kandakuliya of the Kalpitiya peninsula of Sri Lanka, a seasonal fishery for flying fish exists. The fishing operations are mainly carried out by 37 FRP boats, using gillnets of $3.4 \mathrm{~cm}$ and $4.5 \mathrm{~cm}$ stretch mesh sizes. In the present study, the fishery was investigated in two consecutive fishing seasons: from October 2002 to April 2003 and from October 2003 to April 2004.

Total catch, effort and catch per unit effort (CPUE) showed seasonal variations. During the period of investigation, the highest catch was in November 2002 while the lowest catch was reported in March 2003. Fishing effort was high in November 2002 and remained at a more or less steady level till February 2003. The mean CPUE varied from $102 \pm 37.8$ to $224 \pm$ $82.7 \mathrm{~kg}$ boat $^{-1}$ day $^{-1}$. Total production from this fishery during the study period, was calculated as 488.2 and 519.1 tonnes for 2002/2003 and 2003/ 2004 seasons respectively. As the CPUE has not declined during the last decade and as fishing effort has declined, it can be concluded that at present, there is no danger of overexploitation of flying fish stocks off northwestern coasts of Sri Lanka. CPUE values recorded during the full moon periods were found to be significantly lower than those recorded during the new moon period and quarter moon periods $(\mathrm{P}<0.0001)$. As such, influence of lunar pattern on the fishery of flying fish should be considered in defining management strategies for the fishery.
\end{abstract}

\section{Introduction}

In Asia, one-fourth of animal protein intake is from fish and a major proportion is from low-valued species mainly small pelagics (Kent 1995; FAO 2000). The small pelagic fish catches in Sri Lanka contribute about $26 \%$ of the total fish production in the country (Ministry of Fisheries and Aquatic Resources, 2008-2009)). The backbone of the fishing industry in Sri Lanka is 
still the coastal pelagic fisheries, which contribute to employment for smallscale fisher-folks inhabiting along the coastal belt (Karunasinghe and Wijeyaratne 1996; Ministry of Fisheries and Aquatic Resources 2008-2009; FAO 2010)

Flying fish (Family: Exocoetidae) is an important group in the pelagic fish catch of the coastal regions of many parts of the world as edible fish as well as a baitfish in many tuna fisheries (Jinadasa 1982; Sosis 2000; FAO 2001). In certain parts of tropical Asia, there are locally important artisanal fisheries for flying fish resources (Rao and Basheeruddin 1973; Lonhurst and Pauly 1987; Pajot 1991; Pajot and Prabhakaradu 1993; Dalzell and Lewis 1988). The flying fish species Hirundichthys affinis is reported to support the largest single-species fishery in the eastern Caribbean (Khokiattiwong et al. 2000).

In Sri Lanka, fisheries for the flying fish are reported off the east coast extending from Pulmoodai to Trincomalee (Jinadasa 1991) and off the northwestern coast at Kandakuliya in Kalpitiya peninsula (Jinadasa 1972; Jayawardana and Dayaratne 1998). Off Kandakuliya on the northwestern coast of Sri Lanka (Figure 1), a seasonal fishery for flying fish exists, which usually lasts less than seven months, extending from October to April in the following year. During this fishing season, fishers from other fishing villages on the northwestern coast such as Wennappuwa and Chilaw migrate to this area (Jayawardana and Dayaratne 1998). Studies on the fisheries of flying fish with some details on the distribution of fishing grounds and their suitability as a baitfish for tuna fisheries have been conducted on the east coast of Sri Lanka (Jinadasa, 1972, 1982, 1985, 1991). Seasonal fluctuations in the fisheries of flying fish are evident, which are believed to be attributed to oceanographic factors (Jinadasa 1985; Jayawardana and Dayaratne 1998). Aggregation of pelagic schooling fish is known to be influenced by light intensity associated with lunar phase (Karunasinghe and Wijeyaratne 1996; Freon and Misund 1999). It is therefore hypothesized that the catch efficiencies of flying fish resources off Kandakuliya are influenced by lunar pattern. In the present study, an attempt is made to investigate the status of the fishery of flying fish resources in Kandakuliya, off northwestern coast of Sri Lanka with special emphasis on the influence of lunar pattern on the catch efficiencies.

\section{Materials and Methods}

Catch and effort data of the flying fish fishery were collected from Kandakuliya (Figure 1), which is one of the three main marine fish landing centres in the Kalpitiya peninsula, Sri Lanka. These data were collected during two fishing seasons; October 2002 to April 2003 and from October 2003 to April 2004. 


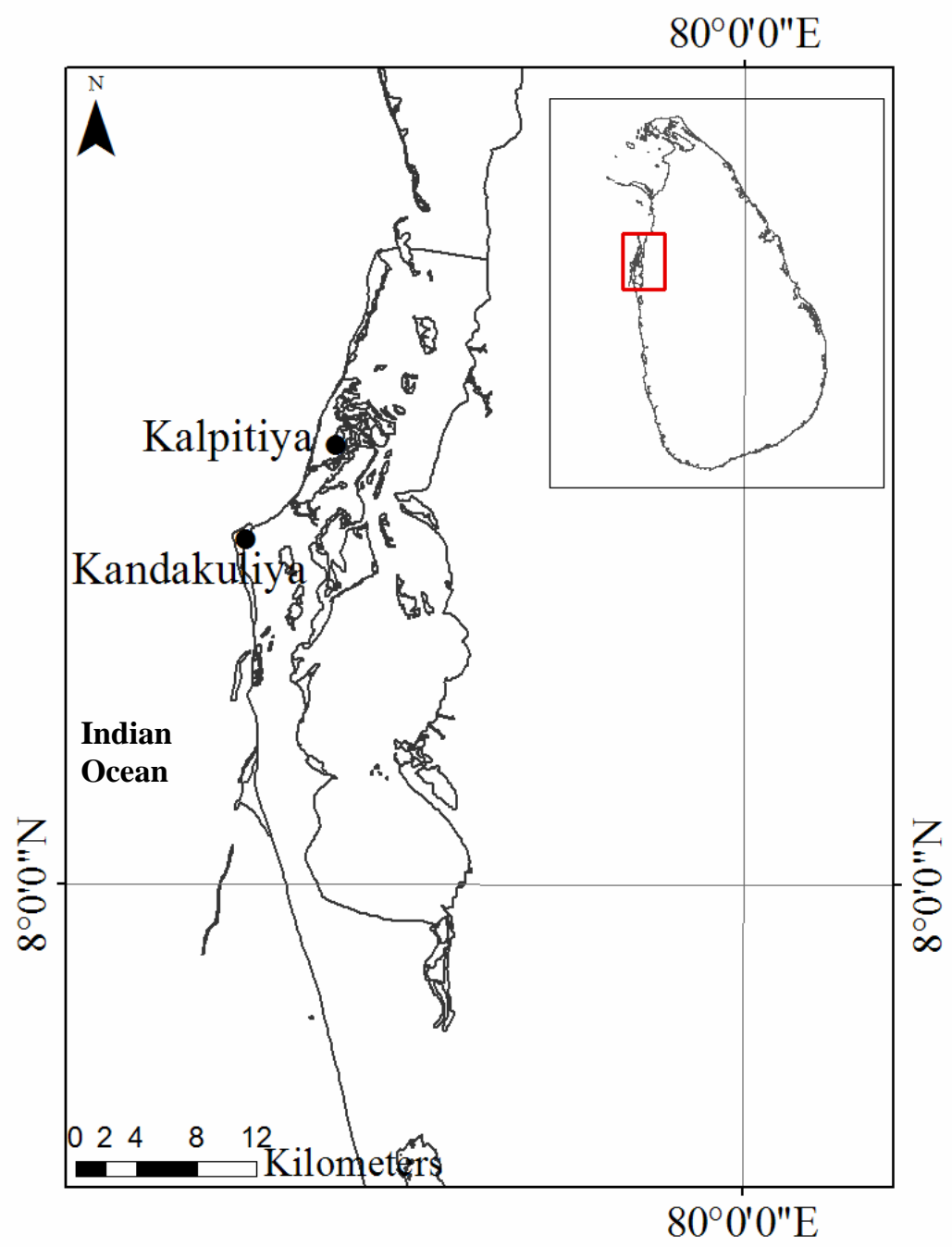

Figure 1. Location of the study area in Sri Lanka

The catch data were collected by making regular weekly visits to Kandakuliya fish landing site taking special care to be present at the time when fishers land their boats with the catch. In Kandakuliya fishing area, 37 fibre-reinforced plastic (FRP) boats of 5 to $5.5 \mathrm{~m}$ in size with outboard motor engines of 25-40 HP are used in the fishery for flying fish. The fishing boats manned by two fishers, start fishing around 4-5 a.m, set gillnets approximately for $6 \mathrm{~h}$ period and return to the landing site in the late afternoon. Around $40 \%$ of the total number of boats operated was sampled randomly and total catch in each of the sampled boats was also noted. The fishing gear was gillnets of nylon multi-filament twine. Number of net pieces of the fleet of nets used in a single operation in each boat was reported by interviewing the fishers and was found to be 60 to 78 net pieces per boat. The 
dimension of nets (each pieces is 1500 mesh long and 110 mesh deep; 3.4 to $4.5 \mathrm{~cm}$ stretched mesh sizes) were more or less uniform in all the boats. The total number of boats operated on a particular day was recorded to estimate the total catch landed per day. Daily data on catches of individual boats were also collected from the log-books of buyers of flying fish catches. In the present analysis, one fishing trip which operated gillnets was considered as a unit effort due to the reason that the type of boat were uniform and that more or less similar number of gillnet pieces was used in each boat. However, it must be noted that mesh range (3.4 to $4.5 \mathrm{~cm}$ ) of gillnets might influence catch efficiencies, but it was disregarded in the present analysis. From these data, catch per unit effort (CPUE) was computed and expressed in kg per boat-day. Total catch and effort for each month were estimated from the data collected on each sampling day. From each boat observed on each sampling day, a sample of 10-12 kg flying fish landed was taken to estimate the species composition.

Total catch and effort data obtained from the log-books of buyers of flying fish landing were used to investigate the effect of lunar pattern on the landings. For this purpose, daily CPUE values expressed as $\mathrm{kg}$ per boat per day were $\ln (\mathrm{X}+1)$ transformed in order to reduce non-normality as CPUE is known to be log-normally distributed (Gulland 1983). The CPUE data were grouped into three lunar phases, i.e., new moon phase, full moon phase and quarter moon phase by combining data of first and second quarters. Mean CPUE values for three different lunar phases (full moon, new moon and quarter moon) were calculated separately for the respective date of lunar phase \pm one day. The $\ln (\mathrm{CPUE}+1)$ data of the three lunar phases were subjected to one-way analysis of variance (ANOVA) to investigate whether the mean CPUE values in different lunar phases are significantly different at $\alpha=0.05$ (Zar 1999).

\section{Results}

In Kandakuliya, the fishing for flying fish took place after the monsoon in the mid September and lasted until the end of April of the following year in 2002-2003 and 2003-2004 seasons during which this study was carried out. There were 13 fish collecting centres in the Kandakuliya fish landing site. Seven different flying fish species were identified in the landing sites during the study period and the two dominant species were Cheilopogon suttoni and C. nigricans. Cypselurus katoptron was caught in negligible numbers in both fishing seasons (Table 1). Fishers used gillnets of mesh size $3.4 \mathrm{~cm}$ when small-sized flying fish species (Hirundichthys oxycephalus) were targeted while gillnet of $4.5 \mathrm{~cm}$ mesh size were used to catch large species (C. suttoni and C. nigricans). At the onset of fishing season in both years, C. suttoni, C. nigricans and Cypselurus poecilopterus dominated the catches while in the latter part of the fishing season (December to March) Hirundichthys oxycephalus contributed in high quantities (Figure 2). 
Table 1. Estimated catch and percentage of flying fish species landed in Kandakuliya fish landing site during fishing seasons of 2002-2003 and 2003-2004.

\begin{tabular}{|c|c|c|c|c|}
\hline \multirow[t]{2}{*}{ Scientific name } & \multicolumn{2}{|c|}{ Length range (cm) } & \multirow{2}{*}{$\begin{array}{c}\text { Catch } \\
\text { (kg) }\end{array}$} & \multirow{2}{*}{$\begin{array}{c}\text { Catch } \\
(\%)\end{array}$} \\
\hline & SL & $\mathrm{TL}$ & & \\
\hline $\begin{array}{l}\text { Cheilopogon nigricans } \\
\text { (Bennett, 1846) }\end{array}$ & $15.2-31.7$ & $19.5-39.2$ & 314,649 & 31 \\
\hline $\begin{array}{l}\text { Cheilopogon suttoni } \\
\text { (Whitley and Colefax, } \\
\text { 1938) }\end{array}$ & $17.6-34.3$ & $23.2-39.3$ & 358,057 & 36 \\
\hline $\begin{array}{l}\text { Cheilopogon cyanopterus } \\
\text { (Valenciennes, 1846) }\end{array}$ & $18.4-35.3$ & $26.0-40.0$ & 14,976 & 1 \\
\hline $\begin{array}{l}\text { Cypselurus naresii } \\
\text { (Günther, 1889) }\end{array}$ & $15-25.5$ & $19.2-28.2$ & 29,641 & 3 \\
\hline $\begin{array}{l}\text { Cypselurus poecilopterus } \\
\text { (Valenciennes, 1846) }\end{array}$ & $14.1-26.4$ & $20.2-36.1$ & 105,436 & 10 \\
\hline $\begin{array}{l}\text { Hirundichthys oxycephalus } \\
\text { (Bleeker, 1857) }\end{array}$ & $12.2-26.8$ & $16.1-35.2$ & 184,541 & 18 \\
\hline $\begin{array}{l}\text { Cypselurus katoptron } \\
\text { (Bleeker, 1866) }\end{array}$ & $15.0-18.0$ & $17-20.2$ & $N / Q$ & $N / Q$ \\
\hline
\end{tabular}

$N / Q$ - landed in negligible quantities.

\section{Fishing effort}

The monthly variations in fishing effort during both fishing seasons were not significantly different $(\mathrm{P}>0.05)$ (Figure 3a). Higher fish effort was exerted in November in 2002/2003 and in December in 2003/2004. In both fishing seasons, low fishing effort was observes in former and latter parts of the seasons in October and March (Figure 3a).

\section{CPUE and total catch}

The peak CPUE (Figure 3b) and peak total catch (Figure 3c) were reported in December in 2003/2004 fishing season (P > 0.05). During 2002/2003 fishing season however, both CPUE and total catch were low in December $(\mathrm{P}>0.05)$. Although total monthly catch showed low variability during both fishing seasons $(\mathrm{P}>0.05)$ (Figure $3 \mathrm{c}$ ), CPUE had high variability in each month $(\mathrm{P}>0.05)$ (Figure $3 b)$. 


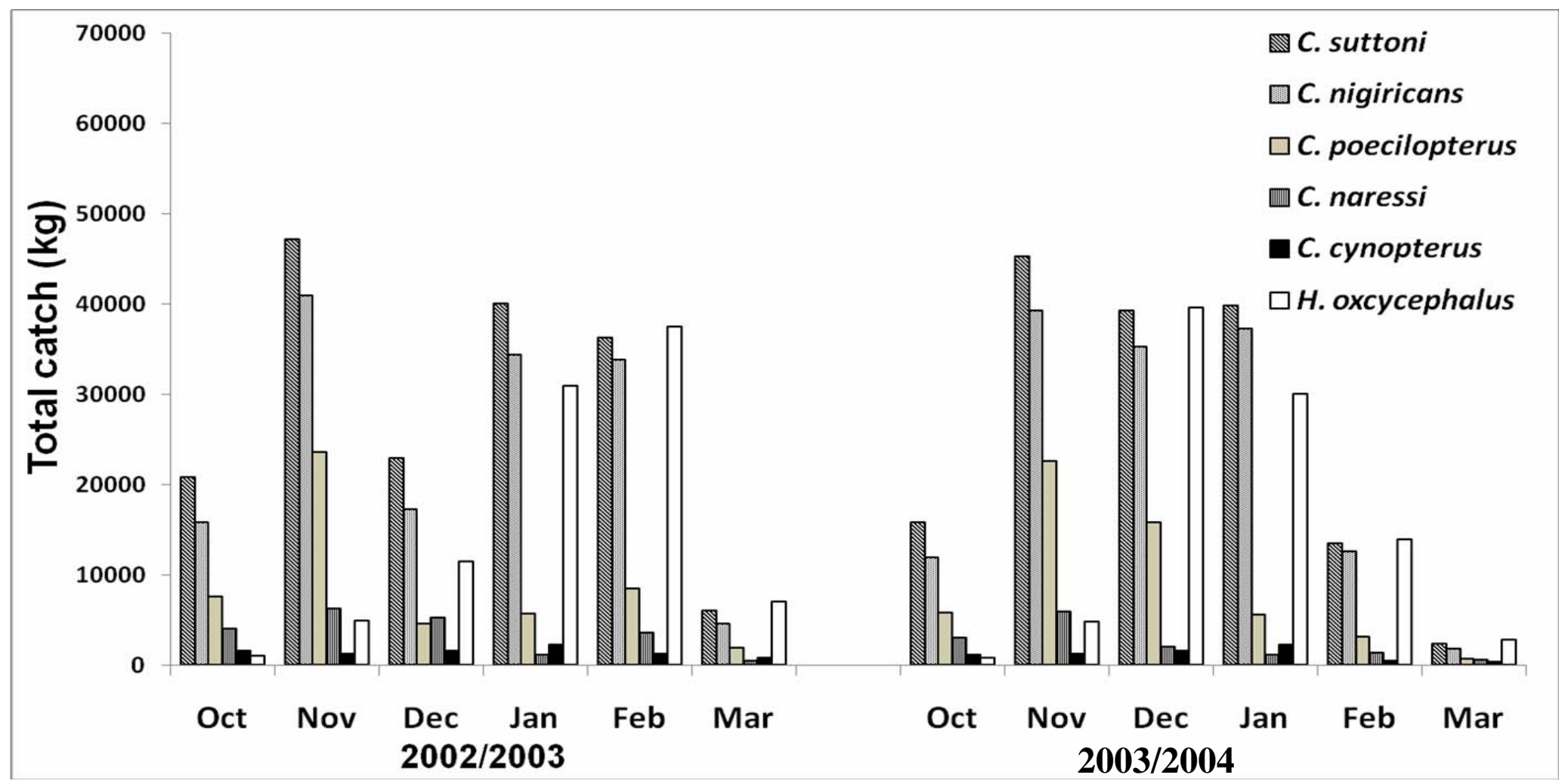

Figure 2. Species-wise monthly catch variations for year 2002/2003 and 2003/2004 

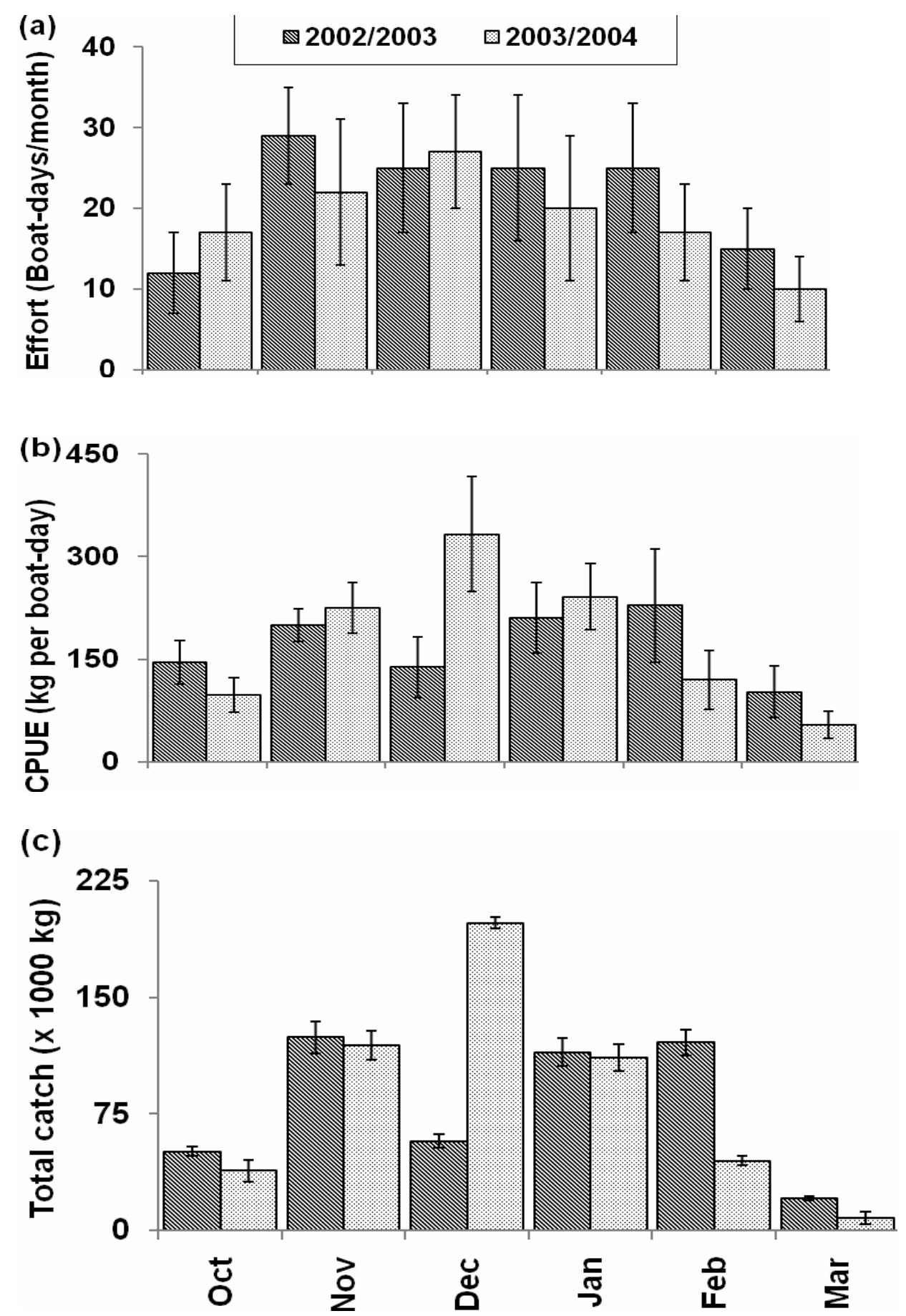

Figure 3. The monthly variations in (a) fishing effort, (b) CPUE and (c) total catch for 2002/03 and 2003/04. 


\section{Effects of lunar phase}

Logarithmic values of mean CPUE during full moon phase and quarter moon phase were lower than that during new moon phase (Figure 4). One-way ANOVA followed by Scheffe's multiple contrast procedure (Zar 1999) indicated that mean CPUE during full moon phase was significantly lower than those in other two lunar phases $(\mathrm{P}<0.0001)$ (Table 2; Figure 4).

Table 2. One way ANOVA for comparison of $\ln (\mathrm{CPUE}+1)$ of flying fish species off Kandakuliya during different lunar phases. df - Degrees of freedom; SS - Sum of squares; MS - Mean square; F - Variance ratio; P Probability level.

\begin{tabular}{llllll}
\hline Source & df & SS & MS & F & P \\
\hline $\begin{array}{l}\text { Lunar } \\
\text { phase }\end{array}$ & 2 & 46.661 & 23.330 & 51.80 & 0.000 \\
Error & 395 & 177.896 & 0.450 & & \\
Total & 397 & 224.557 & & & \\
\hline
\end{tabular}

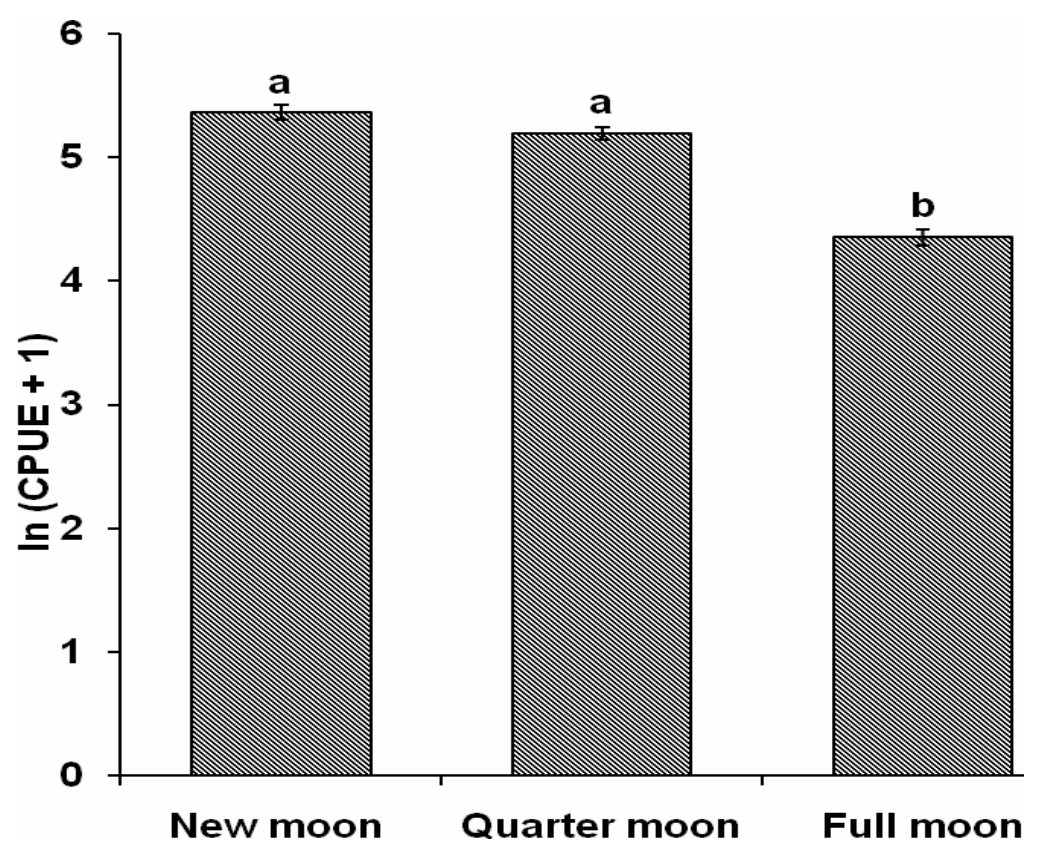

Figure 4. Ln (CPUE+1) during different moon phase. Vertical bars show \pm standard errors of the mean. The bars with same letters are not significantly different. 


\section{Discussion}

The fishery for flying fish off the northwestern coast of Sri Lanka is highly seasonal and lasts from mid September to April of the following year. This is in conformity with the findings of De Bruin et al. (1994) and Jayawardana and Dayaratne (1998), who have also recorded similar fishing seasons for flying fish off the northwestern coast of Sri Lanka. In the eastern coast of Sri Lanka, the fishing season was reported be from mid May to July (Jinadasa 1991). Seasonality of flying fish fisheries along the Coromandel coast in India (Arora and Banerji 1957; Pajot 1991) and eastern Caribbean (FAO 2001) has also been reported.

There was a remarkable monthly variation in flying fish production during the study period and the maximum total production was reported during the months of November and December respectively for both fishing seasons. The monthly CPUE was high from November to January period except in December 2002. Jayawardana and Dayaratne (1998) reported high flying fish production in the months of November, December and March from 1991 to 1993 and stated that this high total production from November to March was due to greater relative abundance of the stocks. Results of the present study also indicated that there were seasonal variations in flying fish production within the fishing season. There was a drastic variation in total production although fishing effort has remained more or less constant. This may probably be due to the influence of environmental conditions such as weather, lunar pattern etc. on the catchability of flying fish.

Mean CPUE value for the flying fish fishery in Kandakuliya during the study period varied from $100 \mathrm{~kg} /$ boat/day to $250 \mathrm{~kg} /$ boat/day, but there was a drastic increase of CPUE value in December 2003. The catch rates reported in the present study were not much different when compared to the catch rates reported by Jayawardana and Dayaratne (1998) for the flying fish fishery in Kandakuliya: $110 \mathrm{~kg} /$ boat/day and $155 \mathrm{~kg} /$ boat/day for the periods 1991-1992 and 1992-1993 respectively. Similar values (118 kg/boat/day) have been obtained from experimental fishing trials for flying fish during the periods 1989-1991 in the Coromandel coast of India (Pajot and Prabhakaradu, 1993).

In the study area, total annual production from the flying fish fishery during 2002-2003 was estimated to be 489.3 tonnes while it was 519.4 tonnes during 2003-2004 which were comparatively lower than the values reported for the period 1991-1992 (1246 tonnes) and 1992-1993 (1724 tonnes) (Jayawardana and Dayaratne 1998).

The present analysis indicated significantly low CPUE during the full moon period than those recorded during the new moon period and quarter moon period. In pelagic fish stocks, fish aggregation may change according to the phase of the moon, probably due to light intensity which influences catchability (Freon and Misund 1999). Higher CPUE values during the new moon day have been observed by many authors for several small pelagic fish species. According to Freon and Misund (1999), during the new moon, the 
small pelagic fish were at the depths of 10-20 m, while at full moon, they were much closer to the bottom. Luecke and Wurtsbaugh (1993) reported that fish were close to the surface when light intensity in the water column is lower and therefore more vulnerable to nets. On the other hand it is interesting to note that Amblygaster sirm shows significantly higher CPUE values during the full moon period (Karunasinghe and Wijeyaratne 1996). Hamley (1975) has stated that visibility of the net would bring about low catchability due to the avoidance behaviour of fish and that this avoidance behaviour decreased with decreasing light intensity. The significantly low CPUE of flying fish off Kandakuliya during full moon period found in the present study, must therefore be due to the ability of flying fish to avoid gillnets during full moon period. On the other hand, many workers had shown the negative correlation of planktonic organisms with moon light intensity specially during their vertical migration. Flying fishes usually swim in schools, live in epipelagic zone, and feed mainly on zooplankton (Longhurst and Pauly 1987). Perhaps this flying fish aggregation might be due to availability of planktonic food organisms, which is influenced by the lunar pattern.

The number of net pieces used in the drift gill net fishery for flying fish varied from 60-78. Nevertheless, previous studies have revealed that during 1991-1993 period, average number of net pieces used for single operation was 98 (Jayawardana and Dayaratne 1998). This indicates that there has been a drastic decline in total fishing effort for flying fish since 1991. As CPUE has remained more or less constant, the fish stock abundance might have not changed since 1991.

The mesh sizes, which are used to catch flying fish species in the Kandakuliya are $3.4 \mathrm{~cm}$ and $4.5 \mathrm{~cm}$ and this falls within the range previously recorded range of $2.9 \mathrm{~cm}$ to $4.8 \mathrm{~cm}$ (Jayawardana and Dayaratne 1998). This indicates that the size compositions of flying fish species in the fishing area have also remained unchanged.

The main fishing vessel used for this fishery was 5 to $5.5 \mathrm{~m}$ fiberglass boats with 25 to $40 \mathrm{HP}$ outboard engines. Nevertheless, there has been a declining trend of total number of boats engaged in this fishery (38 boats) than 94-106 boats in 1991 -1993 (Jayawardana and Dayaratne 1998). The decline in total flying fish production can therefore be due to declined fishing effort.

According to the present study, there are seven dominant species in the catches. Dominance of five species out of seven has also been reported by Jayawardana and Dayaratne (1998). Cypselurus naresii and Cypselurus katoptron were not recorded by Jayawardana and Dayaratne (1998), while Cheilopgan furcatus, Hirunddichthys coromandelensis and two Hemiramphidae species; Oxporhamphus spp. and Hyporhamphus limbatus which were reported by them were not recorded in the present study.

As the CPUE has not declined during the last decade and as fishing effort has declined, it can be concluded that at present, there is no danger of overexploitation of flying fish stocks off northwestern coasts of Sri Lanka. 
Furthermore, the influence of lunar pattern on the fishery of flying fish should be considered in defining management strategies.

\section{Acknowledgements}

The author is grateful to Professor U.S. Amarasinghe, Department of Zoology, University of Kalaniya for his guidance throughout the study and help in preparing this manuscript. Scholarship awarded to the author by the Asian Development Bank, Science and Technology Personnel Developmental Project is also gratefully acknowledged.

\section{References}

Arora, H.L. \& S.K. Banerji 1957.

Flying fish fishery along the Coromandel Coast. Indian Journal of Fisheries. 4: 80-91.

Dalzell P. \& A.D. Lewis 1988.

Fisheries for small pelagic in the Pacific Islands and their potential yield. South Pacific Commission Workshop on Inshore Fishery Resources, 14-25 March 1988: Noumea. 44p

De Bruin, H.P.G., B.C. Russel \& A. Bogusch 1994.

TheMarine Fishery Resources of Sri Lanka. FAO species identification field guide for fishery purposes. FAO, Rome.

FAO, 2000.

The State of World Fisheries and Aquaculture 2000. FAO, Rome, Italy.

FAO, 2001.

Western Central Atlantic Fisheries Commission Report of the Second meeting of the Flying fish working group of the Eastern Caribbean. Bridgetown, Barbados, 8.12 January 2001. SLAC/R670.

FAO 2010.

Fisheries and Aquaculture Country Profiles, Sri Lanka. Retrieved February 2000, from http:/www.fao.org/fishery/countrysector/FICP_LK/en

Freon, P. \& O.A. Misund 1999.

Dynamics of pelagic fish distribution and behavior: effects on fisheries and stock assessment. Oxford; Fishing News Book. 37-39.

Gulland, J.A. 1983.

Fish Stock Assessment. A Manual of Basic Methods. John Wiley, New York.

Hamley, J.M. 1975.

Review of gillnet selectivity. Journal of the Fisheries Research Board

Canada 32: 1943-1969.

Jayawardana, P.A.A.T. \& P. Dayaratne 1998.

A preliminary analysis of the flying fish fishery off Kandakuliya in Sri Lanka. Ceylon Journal of Science (Bio-Science). 26: 18-28. 
Jinadasa, J. 1972.

Bionomics of the flying fish Hirundichthys coromandelensis (Hornell). Thesis submitted for the degree of Master of Science of the Vidyodaya University of Ceylon.

Jinadasa, J. 1982.

Predators of flying fish (Hirundichthys coromandelensis) and its suitability as a bait fish. Vidyodaya Journal of Arts, Science and Letters, Silver Jubilee Volume. 73-84 pp. Vidyodaya University, Sri Lanka.

Jinadasa, J. 1985.

A study of some oceanographic factors off Trincomalee in Relation to flying fish fishery. Vidyodaya Journal of Arts, Science and Letters 9(1\&2): $15-28$.

Jinadasa, J. 1991.

Fishing ground for the flyingfish $H$. coromandelensis off the east Coast of Sri Lanka. Journal of the National Science Council of Sri Lanka, 19 (2): 107-104.

Karunasinghe, W.P.N. \& M.J.S. Wijeyaratne 1996.

Effects of monsoonal currents, rain fall and lunar phase on the abundance of Amblygaster sirm in the coastal waters off Negombo, Sri Lanka. Sri Lanka Journal of Aquatic Science. 1: 53-58.

Kent, G. 1995.

Aquaculture and food security. Paper presented at the Pacific Congress on Marine Science and Technology, Honolulu, USA, 17 April 1995.

Khokiattiwong, S. R. Mahon,\& W. Hunte 2000.

Seasonal abundance and reproduction of the fourwing flyingfish, Hirundichthys affinis, off Barbados. Environmental Biology of Fishes 59: 43-60.

Longhurst, A.R. \& D. Pauly 1987.

Ecology of Tropical Oceans Academic Press, London.

Luecke, K. \& T.G. Wurtsbaugh. 1993.

Habitat selection and migration. In: Dynamics of Pelagic Fish

Distribution and Behavior (P.Freon and O.A. Misund eds) pp 37-39,

Fishing News Books. Blackwell.

Ministry of Fisheries and Aquatic Resources (2008 - 2009).

Annual Fisheries statistics. Retrieved February 20, 2000, from http://www.fisheries.gov.lk/statistics.html

Pajot, G. 1991.

Capture of flying fish. Findings of BOBP trials and studies. Bay of Bengal News, March 3-19.

Pajot, G \& C.R. Prabhakaradu. 1993.

Flying fish fishing on the Coromandel Coast, 1988-1991 BOBP/WP/84, Bay of Bengal Programme, Madras.

Rao, K.S. \& S. Basheeruddin 1973. 
Unusual catches of flyingfish, Parexocoetus brachypterus (Richardson) in inshore waters at Madras. Indian Journal of Fisheries 20: 629-634.

Sosis, R. 2000.

Costly signaling and torch fishing on Ifaluk Atoll. Evolution and Human Behavior. 21. p 223--244

Zar, J.H. 1999.

Biostatistical Analysis. Fourth Edition. Prentice-Hall Inc. England. Wood Cliffs, N.J. 
